Richards, P. Stratton, R. Mariella, Jr., and F. Milanovich. 1999. PCR detection of bacteria in seven minutes. Science 284:449-450.

3.Cha, R.S. and W.G. Thilly. 1995. Specificity, efficiency, and fidelity of PCR, p. 37-51. In C.W. Dieffenbach and G S. Dveksler (Eds.), PCR Primer: A Laboratory Manual. CSH Laboratory Press, Cold Spring Harbor, NY.

4.Chiou, J., P. Matsudaira, A. Sonin and D. Ehrlich. 2001. A closed-cycle capillary polymerase chain reaction machine. Anal. Chem. 73:2018-2021.

5.Friedman, N.A. and D.R. Meldrum. 1998. Capillary tube resistive thermal cycling. Anal. Chem. 70:2997-3002.

6.Giordano, B.C., J. Ferrance, S. Swedberg, A.F.R. Hühmer, and J.P. Landers. 2001 Polymerase chain reaction in polymeric microchips: DNA amplification in less than 240 seconds. Anal. Biochem. 291:124-132.

7.Hühmer, A.F.R. and J.P. Landers. 2000. Noncontact infrared-mediated thermocycling for effective polymerase chain reaction amplification of DNA in nanoliter volumes. Anal. Chem. 72:5507-5512.

8.Khandurina, J., T.E. McKnight, S.C. Jacobson, L.C. Waters, R.S. Foote, and J.M. Ramsey. 2000. Integrated system for rapid PCR-based DNA analysis in microfluidic devices. Anal. Chem. 72:2995-3000.

9.Kopp, M.U., A.J. de Mello, and A. Manz. 1998. Chemical amplification: continuousflow PCR on a chip. Science 280:1046-1048.

10.Lagally, E.T., I. Medintz, and R.A. Mathies. 2001. Single-molecule DNA amplification and analysis in an integrated microfluidic device. Anal. Chem. 73:565-570.

11.Lagally, E.T., P.C. Simpson, and R.A. Mathies. 2000. Monolithic integrated microfluidic DNA amplification and capillary electrophoresis analysis system. Sensors Actuators B 63:138-146.

12.Nakano, H., K. Matsuda, M. Yohda, T. Nagamune, I. Endo, and T. Yamane. 1994. High speed polymerase chain reaction in constant flow. Biosci. Biotechnol. Biochem. 58:349-352.

13.Wetmur, J.G. 1991. DNA probes: applications of the principles of nucleic acid hybridization. Crit. Rev. Biochem. Mol. Biol. 26:227-259.

14.Wetmur, J.G. and N. Davidson. 1968. Kinetics of renaturation of DNA. J. Mol. Biol. 31:349-370.

15.Wilding, P., M.A. Shoffner, and L.J. Kricka. 1994. PCR in a silicon microstructure. Clin. Chem. 40:1815-1818.

16.Wittwer, C.T., G.C. Fillmore, and D.J. Garling. 1990. Minimizing the time required for DNA amplification by efficient heat transfer to small samples. Anal. Biochem. 186:328331 .

17.Wittwer, C.T., G.C. Fillmore, and D.R. Hillyard. 1989. Automated polymerase chain reaction in capillary tubes with hot air. Nucleic Acids Res. 17:4353-4357.

18.Wittwer, C.T. and D.J. Garling. 1991. Rapid cycle DNA amplification: time and temperature optimization. BioTechniques 10:76-83.

19.Wittwer, C.T., K.M. Ririe, R.V. Andrew, D.A. David, R.A. Gundry, and U.J. Balis. 1997. The LightCycler ${ }^{\mathrm{TM}}$ : a microvolume multisample fluorimeter with rapid temperature control. BioTechniques 22:176-181.

20.Woolley, A.T., D. Hadley, P. Landre, A.J. deMello, R.A. Mathies, and M.A. Northrup. 1996. Functional integration of PCR amplification and capillary electrophoresis in a microfabricated DNA analysis device. Anal. Chem. 68:4081-4086.

This research was supported by the $\mathrm{Na}$ tional Institutes of Health grant no. HG01389 and the Air Force Office of Scientific Research grant no. F49620-98-1-0235. Address correspondence to Dr. Daniel J. Ehrlich, Whitehead Institute, Room 661, 9 Cambridge Center, Cambridge, MA 02142, USA.e-mail: ehrlich@wi.mit.edu

Received 3 April 2002; accepted 31 May 2002.

Jeffrey T. Chiou, Paul T. Matsudaira, and Daniel J. Ehrlich Whitehead Institute

Cambridge, MA, USA

\section{Linear Amplification of Catalyzed Reporter Deposition Technology on Nylon Membrane Microarray}

BioTechniques 33:564-570 (September 2002)

\section{ABSTRACT}

The application of microarray analysis to gene expression from limited tissue samples has not been very successful because of the poor signal quality from the genes expressed at low levels. Here we discussed the use of catalyzed reporter deposition (CARD) technology to amplify signals from limited RNA samples on nylon membrane cDNA microarray. When the input RNA level was greater than $10 \mu \mathrm{g}$, the genes expressed at high levels did not amplify in proportion to those expressed at low levels. Compared to conventional colorimetric detection, the CARD method requires less than $10 \%$ of the total RNA used for amplification of signal displayed onto a nylon membrane cDNA microarray. Total RNA (5-10 $\mu \mathrm{g})$, as one can extract from a limited amount of specimen, was determined to produce a linear correlation between the colorimetric detection and CARD methods. Beyond this range, it can cause a nonlinear amplification of highly expressed and low-abundance genes. These results suggest that when amplification is needed for any applications using the CARD method, including DNA microarray experiments, precaution has to be taken in the amount of RNA used to avoid skew amplification and thus misleading conclusions.

\section{INTRODUCTION}

The microarray biochip enables life scientists to understand the mechanisms of diseases, develop new drugs and diagnostics, and widen the scope of basic research (16). The sensitive detection of low-abundance mRNA or limited tissue samples is almost impossible using direct labeling strategies. To improve signal detection in scarce biomedical specimens, we applied the catalyzed reporter deposition (CARD) technology (11), a signal amplification technique, to nylon microarrays. The signal output derived from the sequential tyramide amplification should reflect the transcriptional levels of all the genes in a linear fashion and avoid over- and underestimation of the original quantity.

RNA, especially mRNA, is the standard source for performing microarray experiments. However, this biological material is very limited in a number of cases (e.g., cancer samples and lowabundance transcripts from various tissue-specific genes). Thus, signal amplification methods become essential to generate meaningful and reliable data. Recently, a patented technology, Tyramide Signal Amplification ${ }^{\mathrm{TM}}\left(\mathrm{NEN}^{\circledR}\right.$ Life Science Products, Boston, MA, USA) (7-9), also known as the CARD method, has been developed. It amplifies both chromogenic and fluorescent signals in standard immunohistochemistry and in situ hybridization protocols, resulting in a significant increase in sensitivity, with no loss of resolution or an increase in background. This tyramide-based technique allows amplifi- 
cation of fluorescent signals up to 1000-fold $(1,4,15,17,20-22)$. The CARD method was also adopted to explore the gene expression of Helicobacter pylori on membrane microarrays (3). The CARD technique has also been widely used to amplify fluorescent signal for glass cDNA microarrays $(2,13,14,18)$. Only $1 \mu \mathrm{g}$ total RNA is required to conduct an analysis using the CARD technique, and this significantly reduces the starting material by up to 50-fold.

The CARD method is easily integrated into any protocol (Figure 1) after an initial addition of HRP. HRP catalyzes the rapid deposition and binding of a labeled (e.g., biotin or other labeling moieties) tyramide onto tissue sections or cell preparations previously blocked with proteins (19). The free radical intermediate reacts with the tyrosine of the proteins on the section surface. These labels can then be detected by standard chromogenic or fluorescent techniques. Since the added labels are only deposited close to the enzyme site, there is a minimal loss of resolution.

Colorimetric detection has been adopted for use in nylon membrane microarray experiments $(5,12)$. The amount of RNA needed (50-100 $\mu \mathrm{g}$ total RNA) for using colorimetric detection method is very similar to that of the glass/fluorescence microarray system.

Here we utilized nylon cDNA microarrays to examine the gene expression patterns of colorimetric detection and CARD methods under conditions where RNA is limited, as seen in small samples such as medical biopsies. Dilution experiments suggested that amplification of as little as $5 \mu \mathrm{g}$ total RNA can be detected using this approach. Misinterpretation of the results occurred when the starting amounts of RNA fell beyond the $\log$ phase of CARD amplification. The amount of RNA used should be carefully determined in the CARD method not to exceed the upper saturation limit.

\section{MATERIALS AND METHODS}

\section{Cell Culture}

A human embryonic kidney (HEK) cell line was obtained from ATCC (Manassas, VA, USA) and maintained in RPMI supplemented with 10\% FBS (HyClone, Logan, UT, USA).

\section{RNA Isolation and cDNA Probe Labeling}

Total RNA was isolated using TRIzOL ${ }^{\circledR}$ reagent (Invitrogen, Carlsbad, CA, USA) and further purified using the RNeasy ${ }^{\circledR}$ kit (Qiagen, Hilden, Germany).

Total RNA was reverse-transcribed into cDNA using $6 \mu \mathrm{M}$ oligo(dT) primer with $1 \times$ first-strand buffer, $10 \mathrm{mM}$ DTT, $500 \mu \mathrm{M}$ dNTP (dATP, dCTP, and dGTP), $40 \mu \mathrm{M}$ dTTP, $0.125 \mathrm{U} \mathrm{RNasin}^{\circledR}$ (Invitrogen), and $300 \mathrm{U}$ SUPERSCRIPT II $^{\mathrm{TM}}$ (Invitrogen). Biotin-16-dUTP (40 $\mu \mathrm{M}$; Roche Applied Science, Mannheim, Germany) was also incorporated into cDNA synthesis during reverse transcription. The reaction mixture was heated to $70^{\circ} \mathrm{C}$ for $10 \mathrm{~min}$ before the Biotin-16-dUTP and enzymes were added; synthesis was continued at $42^{\circ} \mathrm{C}$ for $90 \mathrm{~min}$, followed by $95^{\circ} \mathrm{C}$ for $5 \mathrm{~min}$ to cease the reaction. The unincorporated nucleotides were removed by precipitating the solution with ethanol for $1 \mathrm{~h}$.

Eureka $^{\mathrm{TM}}$ IV cDNA nylon membrane microarray (U-Vision Biotech, Taipei, Taiwan) was used throughout the project. This cDNA microarray consists of a total of 1765 triplicate human genes in an area of $2.5 \times 3.5 \mathrm{~cm}$, and the DNA was stored as the inserts in bacterial clones. Plasmid of each clone was extracted, and the cDNA was amplified by PCR using vector primers. The PCR products were then concentrated by evaporating at $95^{\circ} \mathrm{C}$ to obtain a concentration of $2-3 \mu \mathrm{g} / \mu \mathrm{L}$ before being spotted onto a positively charged nylon membrane (Roche Applied Science) by using PixSys ${ }^{\mathrm{TM}} 5500$ arrayer (Cartesian, Irvine, CA, USA).

\section{Membrane Hybridization}

Prehybridization was performed for 90 min with $5 \mathrm{~mL}$ hybridization buffer [containing $0.1 \%$ N-lauroylsarcosine, $0.1 \%$ SDS, $1 \%$ Blocking Reagent (Roche Applied Science), and 100 $\mu \mathrm{g} / \mathrm{mL}$ salmon sperm DNA]. Hybridization mixture $(80 \mu \mathrm{L})$ was composed of $4 \mu \mathrm{g}$ biotinylated probe, 0.25 $\mu \mathrm{g}$ human Cot-1 DNA, and $0.25 \mu \mathrm{g}$ poly $(\mathrm{dA})_{10}$ oligomer in the hybridization buffer. After denaturation for $5 \mathrm{~min}$ at $95^{\circ} \mathrm{C}$, the hybridization mixture was added onto the membrane and sealed in a hybridization bag. Hybridization was performed at $63^{\circ} \mathrm{C}$ for $16 \mathrm{~h}$. Membranes were washed twice in $2 \times \mathrm{SSC} / 0.1 \%$ SDS and three times in $0.1 \times \mathrm{SSC} / 0.1 \%$ SDS at room temperature for $5 \mathrm{~min}$ and $63^{\circ} \mathrm{C}$ for $15 \mathrm{~min}$, respectively.

\section{Colorimetric Detection}

After washing at $63^{\circ} \mathrm{C}$, the membrane was blocked with $0.1 \mathrm{M}$ maleic acid, pH 7.5, $0.15 \mathrm{M} \mathrm{NaCl}, 1 \%$ Blocking Reagent, and $2 \%$ dextran sulfate at room temperature for $1 \mathrm{~h}$. To detect the spots on the membrane, the membrane was incubated in a $5-\mathrm{mL}$ mixture containing $0.1 \mathrm{M}$ maleic acid, $\mathrm{pH} 7.5,0.15$ $\mathrm{M} \mathrm{NaCl}, 0.1 \%$ Blocking Reagent, and 700 -fold diluted streptavidin $\beta$-galactosidase (Invitrogen) for $1 \mathrm{~h}$ (Dr. Konan Peck, personal communication). After washing off the excess conjugate with $1 \times \mathrm{PBS}$, the membrane was treated with $1.2 \mathrm{mM} \mathrm{X}$-gal (Invitrogen), $1 \mathrm{mM}$ $\mathrm{MgCl}_{2}, 3 \mathrm{mM} \mathrm{K}_{3} \mathrm{Fe}(\mathrm{CN})_{6}$, and $3 \mathrm{mM}$ $\mathrm{K}_{4} \mathrm{Fe}(\mathrm{CN})_{6}$ for $45 \mathrm{~min}$ at $37^{\circ} \mathrm{C}$. The color development reaction was then stopped by rinsing the membrane several times with deionized water.

\section{CARD}

After hybridization and washing, the membrane was rinsed with 2 mL blocking buffer, containing $1 \times$ PBS, $0.05 \%$ Tween ${ }^{\circledR} 20$, and $7 \%$ casein. Hybridization was detected by first incubating the membrane with $2 \mathrm{~mL}$ conjugation reaction mixture containing $1 \times \mathrm{PBS}, 0.05 \%$ Tween 20, and 1\% BSA, 350-fold diluted HRP-conjugated streptavidin, 4\% PEG-8000, $0.7 \%$ casein at room temperature for $1 \mathrm{~h}$ (Dr. Konan Peck, personal communication). Later, signal amplification was performed for 10 min by using $1 \times$ Biotin-Tyramide reagent (NEN Life Science Products). Biotinyl tyramide was detected using $1 \times$ PBS, $0.05 \%$ Tween $20,1 \%$ BSA, $4 \%$ PEG- $8000,0.7 \%$ casein, and $700-$ fold diluted $\beta$-galactosidase-conjugated streptavidin at room temperature for 1 h. After washing off the excess conjugate with $1 \times$ PBS buffer, the membrane was treated with $1.2 \mathrm{mM} \mathrm{X-gal,} 1 \mathrm{mM}$ $\mathrm{MgCl}_{2}, 3 \mathrm{mM} \mathrm{K}_{3} \mathrm{Fe}(\mathrm{CN})_{6}$, and $3 \mathrm{mM}$ $\mathrm{K}_{4} \mathrm{Fe}(\mathrm{CN})_{6}$ for $45 \mathrm{~min}$ at $37^{\circ} \mathrm{C}$. The 
color development reaction was then stopped by rinsing the membrane several times with deionized water.

\section{Internal Controls}

For controlling the labeling efficiency, a plant gene was labeled together with the human total RNA. For control of color development, a $5 \times 6 \mathrm{~mm}$ nylon membrane containing a total of 192 biotinylated spots (CalibStrip ${ }^{\mathrm{TM}}$; U-Vision Biotech) was used. The first row was spotted with 15 repeats of biotinylated DNA at a known molecular number. The next row was comprised of 16 spots, which were 1.5-fold diluted from the first row. Thus, 12 rows and 16 columns were organized from the highest concentration to the lowest in the last row (ranging from $4 \times 10^{7}$ to $4.6 \times$ $10^{5}$ molecules). Color development on the two strips was then performed with colorimetric detection and CARD methods, respectively.

HybControl $^{\mathrm{TM}}$ (U-Vision Biotech) was a mixture of three biotin-labeled PCR products of plant origin, present in high, medium, and low abundance. They were added into the hybridization mixture together with the labeled human probe before hybridization. These probes after hybridized to their respective DNA spots on the Eureka IV membrane, the signals representing transcripts of different abundance were then measured using quantification software (ImaGene 4.1; BioDiscovery, Los Angeles, CA, USA). These spots served as positive controls for mem-

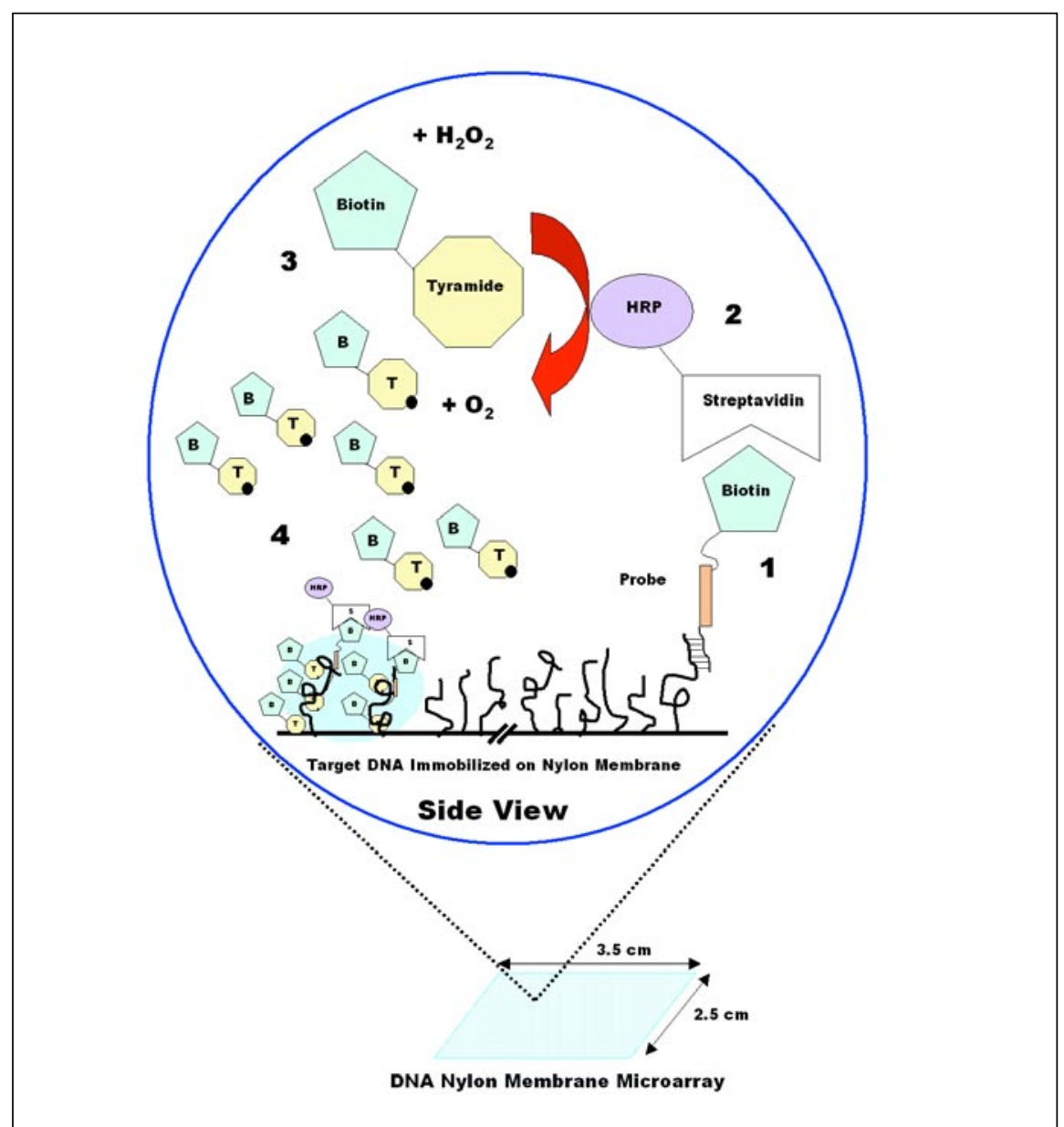

Figure 1. A schematic representation of the mechanism of the signal amplification of CARD adapted onto a nylon membrane cDNA microarray surface. (1) The DNA probe that is hybridized with immobilized DNA on nylon cDNA microarray is detected with a biotin label. (2) HRP-labeled streptavidin added conjugates with the biotin probe, and (3) the HRP catalyzes the oxidation of Biotin-Tyramide. (4) The Biotin-Tyramide radicals are deposited in the vicinity of the target and are further detected by streptavidin and the X-gal system. 
brane hybridization in both methods mentioned earlier.

\section{Image Analysis and Outlier Detection}

A grayscale color image for each microarray membrane was obtained from a PowerLook 3000 flatbed scanner $\left(\mathrm{UMAX}^{\circledR}\right.$, Fremont, CA, USA) with an optical resolution of 3048 dpi. Data obtained from ImaGene 4.1 were normalized for each membrane so that the cDNA microarray results could be compared with each other.

$$
\text { Normalized Intensity }=\frac{m_{i j}}{l}
$$

where

$$
\begin{aligned}
& m_{i j}=\text { Mean Intensity }- \text { Background } \\
& i=\text { No. of row } \\
& j=\text { No. of column } \\
& l=\sqrt{\sum_{i=1}^{65} \sum_{j=1}^{84} m_{i j}^{2}}
\end{aligned}
$$

The normalized value of backgroundsubtracted average signal intensity was reported as the hybridization intensity.

\section{RESULTS}

To determine the optimal RNA amount for CARD amplification, we performed two independent experiments, each with $100 \mu \mathrm{g}$ total RNA from HEK cells for the colorimetric detection method (as control) and 1, 5, 7, 10,50 , and $100 \mu \mathrm{g}$ for the CARD method, respectively, to hybridize on human cDNA nylon microarrays. The signal from each spot of all microarrays was measured, and the signals from each microarray were normalized. Normalized data from colorimetric detection method using $100 \mu \mathrm{g}$ mRNA (COLOR100 in Figures 2 and 3) were then plotted against those of CARDs to confirm their correlations (scatter plots). Since the colorimetric detection method can produce a very linear relationship between the RNA input and the signal intensity, we used colorimetric detection as a standard for the amplification using the CARD method. The best concentration of RNA used in the CARD method was then determined by showing the most linear scatter plot (Figure 2).
Comparison between the normalized hybridization intensities from two repeated experiments (e.g., COLOR1001 vs. COLOR100-2) showed that membrane microarrays gave consistent results with a correlation coefficient of 0.94 (Figure 2, A and B).

When the normalized data were plotted between COLOR100 and CARD from various amounts of RNA input, the linear correlation started to disappear when the starting RNA for CARD method was higher than $10 \mu \mathrm{g}$ (Figure 2, C-F). As shown in Figure 2, $\mathrm{E}$ and $\mathrm{F}$, the signal intensities using the CARD method started to plateau or become saturated even for those mediumor low-abundance transcripts (arrows in Figure 2, E and F). However, $1 \mu \mathrm{g}$ total RNA generated signal intensities too low for data analysis (data not shown). More importantly, a more linear plot started to appear when the RNA input was less than $10 \mu \mathrm{g}$ (Figure 2, C and D). Further experiments showed that the most linear pattern occurred when 7 $\mu \mathrm{g}$ RNA were used, which gave a correlation coefficient of 0.88 (Figure $3 \mathrm{~A}$ ).

When the fold change in signal intensity of spots between CARD and COLOR100 was plotted for every gene, the graph showed that there was a large fluctuation in the fold change of CARD100 (Figure 3B). The mean fold change of CARD100 was 1.35 , with a standard deviation of 1.19 , and CARD7 was 0.75 with a standard deviation of 0.48 . The large variation in magnification of signal in CARD100 was due to the fact that 340 genes out of 1765 in CARD100 had been selectively magnified up to 10 -fold. The signals of most of these genes were low in the colorimetric detection method.

CARD nylon microarrays with starting RNA of 5, 7, 10, and $50 \mu \mathrm{g}$ exhibited a smaller fluctuation of fold change, with a standard deviation of less than 0.6 for all the genes calculated, compared to that from CARD100 with a standard deviation of 1.19 (Table 1). Therefore, data from CARD100 were not reliable compared with those of CARD5, 7, 10, and 50.

\section{DISCUSSION}

In this study, we showed that the CARD method was not applicable to all ranges of starting RNA material for nylon cDNA microarray study. We have determined the optimal amount of RNA to allow linear amplification of

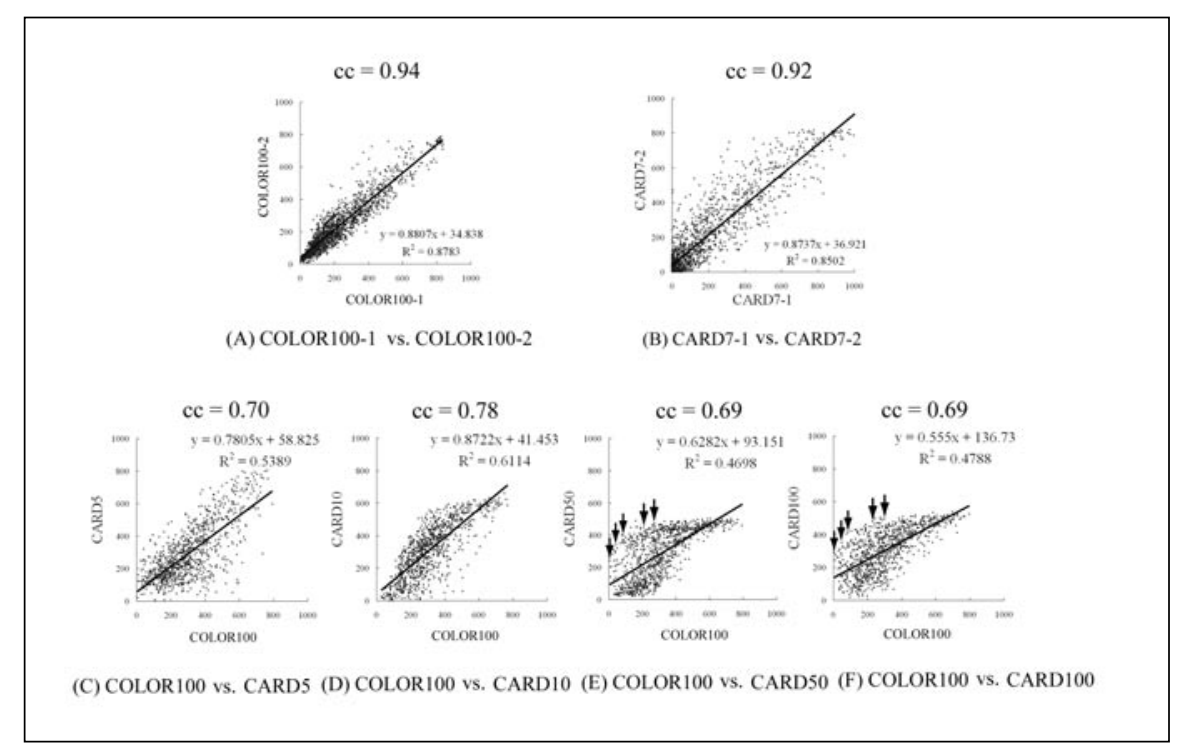

Figure 2. Scatter plots of signals from the microarray experiments. Parts A and B are from two repeated experiments. They showed the high internal reproducibility of colorimetric detection and CARD cDNA microarray when using 100 and $7 \mu \mathrm{g}$ as total RNA input, respectively. Parts C-F are scatter plots of signal comparing the colorimetric detection and CARD methods of different amounts of RNA input. Linear regression analysis was performed on each plot, and the correlation coefficient (cc) is shown at the top of each figure. The arrows indicate the five genes out of many that are preferentially amplified by CARD method. The same five genes are indicated in both parts E and F. COLOR, colorimetric detection. 
Table 1. Relative Fold Changes and Their Standard Deviations of Signal by CARD versus Colorimetric Detection Method

\begin{tabular}{|llc|}
\hline & $\begin{array}{c}\text { Relative Fold } \\
\text { Change }\end{array}$ & $\begin{array}{c}\text { SD of } \\
\text { Fold Change }\end{array}$ \\
\hline CARD5 & 0.53 & 0.60 \\
CARD7 & 0.75 & 0.47 \\
CARD10 & 0.68 & 0.60 \\
CARD50 & 1.14 & 0.5 \\
CARD100 & 1.35 & 1.19 \\
\hline
\end{tabular}

signal for this application. The first set of experiments showed that RNA input between 5 and $10 \mu \mathrm{g}$ produced a good correlation between colorimetric detection and CARD methods, and further experiments with finer scale concluded that $7 \mu \mathrm{g}$ RNA gave the highest linearity between the CARD and colorimetric detection methods. Hence, only approximately $7 \%$ of the amount of sample required for colorimetric detection is required in the CARD method.

With the large RNA input in the CARD method, the fold of amplification among different genes fluctuated, the stronger signals from some genes can be amplified up to 10-fold compared to the colorimetric detection method (arrows in Figure 2, E and F). While genes expressed at low levels are amplified linearly, high-abundance genes are amplified nonlinearly. The distortion of signals occurs less severely when RNA input is less (compare Figure 2F with Figure 2D), even with high-abundance transcripts. When starting RNA in the CARD method reduces to $7 \mu \mathrm{g}$, the correlation of signals from the two methods is highest, and the variations of signal from all genes between the two methods, CARD7 and COLOR100, are smaller (Figure 3 and Table 1). The selective amplification of some genes occurs most significantly in CARD100; therefore, the data from CARD100 are less reliable than others (Table 1). In contrast to what we find here, the colorimetric detection method itself has a very linear signal intensity-probe concentration relationship (12) and, thus, is used as a standard for comparison.

In a labeling system such as colorimetric detection or CARD, the signals generated should be proportional to the

A

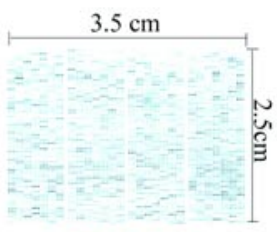

COLOR 100

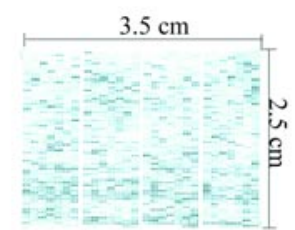

CARD7

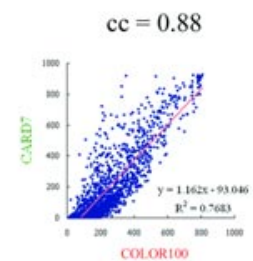

COLOR100 vs. CARD7

B

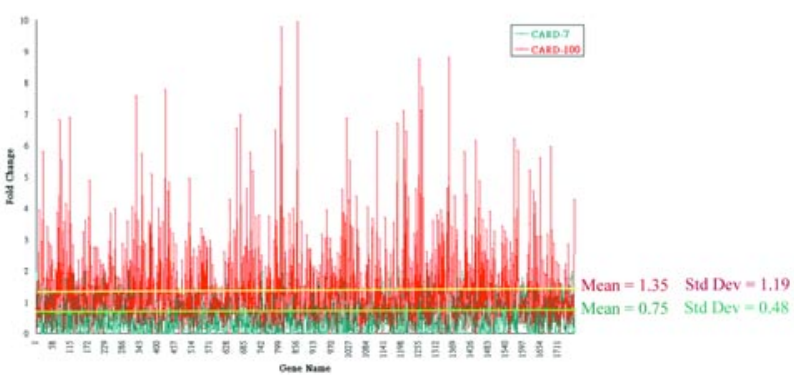

Figure 3. Sample RNA ( $7 \mu \mathrm{g})$ generates more reliable data in the CARD method. (A) The left two pictures are the images of the microarray using the COLOR100 and CARD7 methods. The right-hand panel shows the scatter plot of the normalized signals from the two methods with correlation coefficient $(\mathrm{cc})=0.88$. (B) The relative fold change of signal of individual gene between CARD method and colorimetric detection method was plotted. The red line represents fold change between CARD100 over COLOR100, and the green line represents that of CARD7 and COLOR100. The mean fold change and standard deviation of all genes in the experiment are shown to the right of the plot. The lines show where the values of the mean of both plots. Std Dev, standard deviation; COLOR, colorimetric detection. 
amount of input RNA. To achieve this, all reagents present in the system are in excess, except the biotinylated probe hybridized on the membrane. The HRP present in the system is proportional to the amount of biotin-probe because of the stoichiometric tight conjugation between them. The amount of activated tyramide-biotin generated is proportional to the amount of HRP present. However, this system is disturbed when too much probe or HRP is present; a high level of biotin-tyramide radical is generated, which favors the formation of dimer instead of reacting with the tyrosine residues of the protein on the membrane $(6,10)$. The spot intensities of those genes cannot be developed fully. For those DNA spots with lower abundance, the amount of HRP associated is not present at high concentration, and the tyramide radicals produced are preferentially deposited on the membrane rather than dimerization. The intensities of spot are thus proportional to the transcript levels.

From these experiments, we conclude that a careful determination of starting amount of RNA is of paramount importance in microarray experiments, not to exceed the log phase of CARD amplification.

\section{REFERENCES}

1.Adams, J.C. 1992. Biotin amplification of biotin and horseradish peroxidase signals in histochemical stains. J. Histochem. Cytochem. 40:1457-1463.

2.Adler, K., J. Broadbent, R. Garlick, R. Joseph, A. Khimani, A. Mikulskis, P. Rapiejko, and J. Killian. 2000. MICROMAX $^{\mathrm{TM}}$ : a highly sensitive system for differential gene expression on microarrays, $\mathrm{p}$. 221-230. In M. Schena (Ed.), Microarray Biochip Technology. Eaton Publishing, Natick, MA.

3.Ang, S., C.Z. Lee, K. Peck, M. Sindici, U. Matrubutham, M.A. Gleeson, and J.T. Wang. 2001. Acid-induced gene expression in Helicobacter pylori: study in genomic scale by microarray. Infect. Immun. 69:16791686.

4.Berghorn, K.A., J.H. Bonnett, and G.E. Hoffman. 1994. cFos immunoreactivity is enhanced with biotin amplification. J. Histochem. Cytochem. 42:1635-1642.

5.Bertucci, F., K. Bernard, B. Loriod, Y.C. Chang, S. Granjeaud, D. Birnbaum, C. Nguyen, K. Peck, and B.R. Jordan. 1999. Sensitivity issues in DNA array-based expression measurements and performance of nylon microarrays for small samples. Hum. Mol. Genet. 8:1715-1722.
6.Bobrow, M.N., T.D. Harris, K.J. Shaughnessy, and G.J. Litt. 1989. Catalyzed reporter depostion, a novel method of signal amplification. Applications to immunoassays. J. Immunol. Methods 125:279-285.

7.Bobrow, M.N. and G.J. Litt, inventors; E.I. Du Pont de Nemours and Company, assignee. Method for the detection or quantitation of an analyte using an analyte dependent enzyme activation system. US Patent 5 196306. 1993 March 23.

8.Bobrow, M.N. and G.J. Litt, inventors; E.I. Du Pont de Nemours and Company, assignee. Method for detection or quantitation of an analyte using an analyte dependent enzyme activation system. US Patent 5583001. 1996 Dec. 10.

9.Bobrow, M.N. and G.J. Litt, inventors; E.I. Du Pont de Nemours and Company, assignee. Catalyzed reporter deposition. US Patent 5731 158. 1998 March 24.

10.Bobrow, M.N., G.J. Litt, K.J. Shaughnessy, P.C. Mayer, and J. Conlon. 1992. The use of catalyzed reporter deposition as a means of signal amplification in a variety of formats. J. Immunol. Methods 150:145-149.

11.Bobrow, M.N., K.J. Shaughnessy, and G.J. Litt. 1991. Catalyzed reporter deposition, a novel method of signal amplification. J. Immunol. Methods 137:103-112.

12.Chen, J.J., R. Wu, P.C. Yang, J.Y. Huang, Y.P. Sher, M.H. Han, W.C. Kao, P.J. Lee, et al. 1998. Profiling expression patterns and isolating differentially expressed genes by cDNA microarray system with colorimetry detection. Genomics 51:313-324.

13.Heiskanen, M.A., M.L. Bittner, Y. Chen, J. Khan, K.E. Adler, J.M. Trent, and P.S. Meltzer. 2000. Detection of gene amplification by genomic hybridization to cDNA microarrays. Cancer Res. 60:799-802.

14.Karsten, S.L., V. Van Deerlin, C. Sabatti, L.H. Gill, and D.H. Geschwind. 2002. An evaluation of tyramide signal amplification and archived fixed and frozen tissue in microarray gene expression analysis. Nucleic Acids Res. 30:2e4.

15.Merz, H., R. Malisius, S. Mannweiler, R. Zhow, W. Hartmann, K. Orscheschek, P. Moubayed, and A.C. Feller. 1995. Immunomax. A maximized immunohistochemical method for the retrieval and enhancement of hidden antigens. Lab. Invest. 73:149-156.

16.Ramsay, G. 1998. DNA chips: state-of-theart. Nat. Biotechnol. 16:40-44.

17.Sanno, N., A. Teramoto, M. Sugiyama, Y. Itoh, and R.Y. Osamura. 1996. Application of catalyzed signal amplification in immunodetection of gonadotropin subunits in clinically nonfunctioning pituitary adenomas. Am. J. Clin. Pathol. 106:16-21.

18.Schena, M. and R.W. Davis. 2000. Technology standards for microarray research, p. 1-18. In M. Schena (Ed.) Microarray Biochip Technology. Eaton Publishing, Natick, MA.

19.Speel, E.J.M., A.H.M. Hopman, and P. Komminoth. 1999. Amplification methods to increase the sensitivity of in situ hybridization: play $\operatorname{CARD}(\mathrm{S})$. J. Histochem. Cytochem. 47:281-288.

20.Von Wasielewski, R., M. Mengel, S. Gignac, L. Wilkens, M. Werner, and A. Georgii.
1997. Tyramide amplification technique in routine immunohistochemistry. J. Histochem. Cytochem. 45:1455-1459.

21.Werner, M., R. Von Wasielewski, and P. Komminoth. 1996. Antigen retrieval, signal amplification and intensification in immunohistochemistry. Histochem. Cell. Biol 105:253-260.

22.Zaitsu, K. and Y. Ohkura. 1980. New fluorogenic substrates for horseradish peroxidase: rapid and sensitive assays for hydrogen peroxide and the peroxidases. Anal. Biochem. 109:109-113.

This work was supported by Taiwan Small Business Investment Research grant no. IZ 900033 and NSC 90-2317-B-001001, issued by the Taiwan Ministry of Economic Affairs and the National Science Council, for developing microfabricated diagnostic kits. We thank Dr. Ming-Hua Hsieh of U-Vision Biotech for his help and comments on bioinformatics and discussion on statistical analysis of data, and Dr. Konan Peck from Academia Sinica, Taiwan, for his advice on the protocols of colorimetric detection and CARD. Address correspondence to Ms. Jing-Tyan Ma and Dr. ChiMeng Tzeng, U-Vision Biotech, $3 F$ No. 132, Lane 235, Pao-Chiao Rd., Hsin-Tien City, 231 Taipei, Taiwan. e-mails: cmtzeng@uvision-biotech.com and jeanma@u-visionbiotech.com; Web site: www.u-visionbiotech.com.

Received 26 November 2001; accepted 25 April 2002.

Wai Kwan Lau, Sung-Kay
Chiu, Jing-Tyan Ma, and
Chi-Meng Tzeng
U-Vision Biotech
Taipei, Taiwan

For reprints of this or any other article, contact Reprints@BioTechniques.com 